\title{
Hemicastration in Chilean rodeo stallions in competition
}

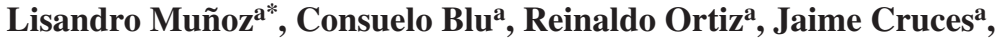 \\ María Cordero $^{\mathrm{b}}$, Mario Briones ${ }^{\mathrm{b}}$
}

\begin{abstract}
The objectives of this study were: a) establish the frequency, age and reason for hemicastration, b) determine the most frequently removed testicle and c) compare the athletic performance between unilaterally castrated and intact Chilean rodeo stallions. Two hundred and sixteen Chilean Horse stallions participating in the 2016 Chilean rodeo qualifying rounds and National Championship (CRNC) were evaluated. Owners and/or riders were interrogated about age, hemicastration, age at hemicastration, removed testicle, reason and effects of hemicastration on athletic performance of stallions. The statistical analysis was descriptive and the results were expressed in means and percentages. Chi-square test was used to compare the performance between unilaterally castrated and intact stallions. Performance was qualified based on qualification to the CRNC and ultimately participation in the Champion series. Fifty-three percent of the stallions were unilaterally castrated (47\% left testicle; 53\% right testicle) $(P>0.05)$. Mean age of hemicastration was $6.97 \pm 2.24$ years. Main reasons reported for hemicastration were: traumatic ( $76 \%)$, increased volume (13\%) and preventive (11\%), but not all of them with medical confirmation. Seven owners or riders were unaware of the reason of hemicastration. Forty-six percent of the qualified stallions to the CRNC $(P>0.05)$ and $29 \%$ of the qualified to the Champion series were unilaterally castrated $(P=0.0122)$. It was concluded that half of the 2016 elite Chilean Horse stallions were unilaterally castrated, without preference for a testicle, after the age of initiation of sporting activity. A $43.5 \%$ of hemicastration in Chilean rodeo stallions are performed preventively or based on subjective assessments of owners and riders without veterinary diagnosis, however, it is unclear that hemicastration affected the athletic performance in these cases.

Key words: hemicastration, stallions, Chilean rodeo.
\end{abstract}

\section{INTRODUCTION}

The main use of the Chilean horse is the Chilean rodeo (García et al 1997), a sport carried out in a circular arena with a sand surface, where two horses with their respective riders must herd a steer at canter. Then, one of the horses performing a lateral canter tries to stop the steer pressing it with its chest against a padded surface (Montory 2016). The Chilean rodeo is an annual competition in which the regional rodeo associations of Chile perform competitions with the objective of achieving the sporting requirements to participate in the qualifying rounds. In the qualifying rounds they compete in order to be part of the 256 horses that participate in the Chilean Rodeo National Championship, a competition that lasts three days and is held once a year. On the last day, the 78 best horses participate in the Champion series of the Chilean Rodeo National Championship of Chile (Arancio 2016).

In the Chilean rodeo the stallions could suffer testicular trauma during the lateral movement at canter, associated with the anatomical position of the testicles and the muscles of the thighs (Apaoblaza 2015). In addition, the risk of suffering a testicular traumatism is greater considering that it has been reported that the testicular size in Chilean

Received: 05.09.2018.

Accepted: 02.01.2019.

aDepartamento de Ciencias Clínicas, Facultad de Ciencias Veterinarias, Universidad de Concepción, Chillán.

bDepartamento de Ciencia Animal, Facultad de Ciencias Veterinarias, Universidad de Concepción, Chillán.

*Corresponding author: L Muñoz; Victoria 495, Concepción, Chile; lismunoz@udec.cl stallions is proportionally greater than expected for a pony (Muñoz-Alonzo et al 2016), and similar to the testicular size of Dutch warmblood stallions or a draft stallions at 4 years of age (Parlevliet et al 1994, Stout and Colenbrander 2011). Muñoz-Alonzo et al (2016), reported that many of the stallions participating in the Chilean rodeo are unilaterally castrated with the purpose of improving their performance. Because there are few studies regarding hemicastration in the Chilean Horse stallions (Apaoblaza 2015, Muñoz-Alonzo et al 2016), the objectives of this study were to: a) establish the frequency, age and reason for hemicastration, b) determine the most frequently removed testicle and c) compare the athletic performance between unilaterally castrated and intact Chilean rodeo stallions participating in the 2016 Chilean rodeo qualifying rounds and National Championship.

\section{MATERIAL AND METHODS}

The study was conducted between February and April 2016. Two hundred and sixteen Chilean Horse stallions were evaluated, from 5 to 20 years old, which correspond to all the stallions participating in the 2016 Chilean rodeo qualifying rounds and National Championship. All these stallions were considered elite horses for participating in the high classes. Individual identification of stallions participating in each event was taken from the website ${ }^{1}$ of the Chilean Rodeo Federation. The owner or rider of each stallion was consulted personally for: name and age of the stallion and if it was unilaterally castrated. If the stallion

http://www.caballoyrodeo.cl/portal_rodeo/stat/port/resultados.html 
was unilaterally castrated, the owner or rider was consulted for: age of the stallion at the time of hemicastration, the side of removed testicle, the reason for the procedure and if they perceived any effect on athletic performance after hemicastration. Then, in all the stallions, the same evaluator made a visual inspection of the testicular area to verify if it was unilaterally castrated and the side of the removed testicle. Once the 2016 Chilean Rodeo National Championship was finished, the results of the participating stallions were obtained from the website ${ }^{2}$ of the Chilean Rodeo Federation. Within all the horses participating in the qualifying rounds of the 2016 competition, the stallions qualified for the Chilean Rodeo National Championship ( $n=68)$ were considered as high performance stallions. Within these high performance individuals, another group of 24 stallions was additionally identified, comprised by the individuals classified to the Champion series of this Championship.

The procedure used in the study was approved by the Ethics Committee of the Faculty of Veterinary Sciences of the Universidad of Concepción.

\section{STATISTICS ANALYSIS}

The statistical analysis of the frequency of hemicastration, of the most removed testicle, age and reasons of hemicastration was descriptive. The results were expressed as percentages, mean and standard deviation. Chi-square test was used to compare athletic performance between unilaterally castrated and intact stallions in three moments: participation in the 2016 qualifying rounds, qualification to the 2016 Chilean Rodeo National Championship and to the Champion series of the 2016 Chilean Rodeo National Championship.

\section{RESULTS AND DISCUSSION}

Out of the participating stallions in the 2016 Chilean rodeo qualifying rounds and National Championship: 115 (53.24\%) were unilaterally castrated and 101 (46.76\%) were intact (included four cryptorchids). The mean age of these was $10.9 \pm 2.24$ years old. There are no studies on the frequency or prevalence of hemicastration in horse population of other breeds or equestrian sports. This could be due to that no other sport equine populations performs lateral canter in the way that the Chilean Horse does. Also, Chilean Horse Stallions have been reported with a high relative testicular size (Muñoz-Alonzo et al 2016). Most of the reports in the literature, correspond to statistical information on the hemicastration of stallions with unilateral testicular lesions (de Ban 1970, Maxwell 2005) or cryptorchidism performed in clinical centers (Cox et al 1979, Varner and Schumacher 1998, Mueller

2 http://www.caballoyrodeo.cl/portal_rodeo/stat/port/resultados.html and Parks 1999, Searle et al 1999, Lu 2005, Marshall et al 2007, Hartman et al 2015, Huppes et al 2017). There is only one study conducted on 507 Chilean Horse stallions in training and or competition, which reported that $13.8 \%$ had been submitted to hemicastration (Apaoblaza 2015). The difference in the frequency of hemicastration between this study and the Apaoblaza (2015) study, could be attributed to the age difference of the evaluated stallions and because in the Apaoblaza (2015) study not all stallions were in competition.

Out of the unilaterally castrated stallions, $46.96 \%$ had the left testicle removed and $53.04 \%$ had the right testicle removed $(P>0.05)$. The absence of statistical differences in relation to the most frequently removed testicle, suggests that there is no predisposition to problems in a certain testicle. This coincides with the study by Muñoz-Alonzo et al (2016), in addition, these researchers reported that in the Chilean Horse stallions there are no significant differences in the size of both testicles in intact stallions.

In relation to age, only 94 owners or riders knew the age of hemicastration. Table 1 shows the number and percentage of unilaterally castrated stallions, by age. The mean age of hemicastration in Chilean Horse stallions was $6.97 \pm 2.24$ years old, suggesting that removal was done shortly after they start training for the praxis of Chilean rodeo, but it is more frequent in the first years of competition. This coincides with another study that reported that hemicastration occurs at the beginning of the training or in the first years of the sports activity (Marshall et al 2007).

Regarding the reasons of hemicastration, seven owners or riders of unilaterally castrated stallions were unaware of the reason of hemicastration. Reported reasons hemicastration $(n=108)$ were: 64 testicular contusion $(59.26 \%)$, 14 testicular size increase $(12.96 \%), 12$ preventive

Table 1. Number and percentage of Chilean rodeo stallions, by age of hemicastration $(n=94)$.

\begin{tabular}{ccc}
\hline $\begin{array}{c}\text { Age of } \\
\text { hemicastration } \\
\text { (years of age) }\end{array}$ & $\begin{array}{c}\text { Number } \\
(\mathrm{n})\end{array}$ & $\begin{array}{c}\text { Percentage } \\
(\%)\end{array}$ \\
\hline 3 & 3 & 3.19 \\
4 & 6 & 6.38 \\
5 & 10 & 10.64 \\
6 & 30 & 31.91 \\
7 & 15 & 15.96 \\
8 & 12 & 12.77 \\
9 & 5 & 5.32 \\
10 & 5 & 5.32 \\
11 & 5 & 5.32 \\
13 & 2 & 2.13 \\
15 & 1 & 1.06 \\
\hline
\end{tabular}


(11.11\%), 10 testicular ascent $(9.26 \%)$ and eight because discomfort when cantering (7.41\%). However, 50 (43.5\%) stallions were unilaterally castrated without a veterinary diagnosis, including 12 stallions unilaterally castrated preventively. Only 65 out of 115 owners or riders were aware of the diagnosis that the veterinarian had made at the time of surgery (36 varicocele, 22 testicular trauma and seven testicular torsions). Surgically, the conditions in which hemicastration is indicated are: varicocele, testicular trauma, testicular tumors, hydrocele, orchitis, periorchitis, and most cases of scrotal hernia (Trotter 1993). This result raises doubts if hemicastration was indicated or not in the 38 stallions whose actual reason is unknown. Testicular contusion and testicular ascent are both attributable to testicular trauma, considering that it is the most frequent testicular alteration in stallions and that it manifests with increased testicular sensitivity and testicular ascent due to the retraction of the cremaster muscle (Varner and Schumacher 1999). In the Chilean Horse stallions, cantering discomfort can also be attributed to testicular trauma (Apaoblaza 2015), especially considering the large testicular size in relation to body size in Chilean Horse stallions (Muñoz-Alonzo et al 2016) already mentioned. However, in the Chilean rodeo stallions the possibility that some musculoskeletal injuries or pathologies could be erroneously attributed by owners or riders to testicular trauma, should not be ruled out. In fact, a study is available, based on clinical records from three veterinary practitioners, reporting musculoskeletal injuries in 114 Chilean rodeo horses and pointing out that $38.6 \%$ of the lameness involves the hindlimbs, with the most frequent lesion being unilateral tarsal osteoarthrosis (Mora-Carreno et al 2014). Because there is no similar background in other equestrian sports, an interesting aspect within the results was the high percentage of stallions that are unilaterally castrated in a preventive manner, probably to avoid a removal surgery while the stallions are in competition. A percentage slightly lower than $20 \%$ reported by Apaoblaza (2015) in Chilean Horse stallions reflect the low perception of risk associated with this surgery, even when there are described complications related to castrations such as anesthetic risks, hemorrhages, infections and evisceration (de Band 1970, Moll et al 1995, Searle et al 1999; Green 2001, Hartman et al 2015, Huppes et al 2017). Also, there seems to be a perception by owners that hemicastration would not affect reproductive performance. Despite the compensatory testicular hypertrophy of the residual testicle, the daily sperm production of a single testicle is significantly lower compared to an intact stallion (Hoagland et al 1986, McCormick et al 2012), which potentially reduces the number of doses that can be obtained from an ejaculate for artificial insemination.

According to the perception of the owners or riders, the athletic performance of the stallions improved after hemicastration in $95.95 \%$ of the cases that was expected in stallions with unilateral testicular problems. However, in $43.5 \%$ of cases a diagnosis had not been made by a veterinarian, so the signs or symptoms attributed by the owner or rider to a unilateral testicular problem could have corresponded to a non-diagnosed musculoskeletal injury. Therefore, in these cases, rest or light exercise and the administration of non-steroidal anti-inflammatory drugs, after hemicastration (Searle 1999, Green 2001), could have reduced or temporarily eliminated the signs of musculoskeletal impairment erroneously attributed to unilateral testicular problems.

In relation to athletic performance, out of the 68 stallions that participated in the 2016 Chilean Rodeo National Championship, $45.59 \%$ of them were unilaterally castrated and $54.41 \%$ were intact $(P>0.05)$. Within the unilaterally castrated, three individuals were preventively unilaterally castrated and ten individuals had no veterinary diagnosis associated to the hemicastration. Out of the 24 stallions that qualified for the Champion series of the 2016 Chilean Rodeo National Championship, 7 (29.16\%) were unilaterally castrated and $17(70.83 \%)$ were intact $(P=0.0122)$. No preventively unilaterally castrated stallions were present and three individuals had been unilaterally castrated without veterinary diagnosis. The significant difference found between the frequencies of unilaterally castrated and intact stallions in the Champion series was unexpected, because in the previous phase of the competition there was no difference between those frequencies. To explain this finding related to the low presence of unilaterally castrated stallions in the high classes of Chilean rodeo competition, we propose that the presence of pre-existing musculoskeletal injuries or pathologies that erroneously led to the hemicastration of the stallions, could reappear and negatively affect athletic performance at times of greater physical exigency, as could happen in the stallions participating in the Champion series.

The main limitations of this study were that some owners or riders did not know the reason and/or age of hemicastration of their stallion and that they did not have a definitive diagnosis of the supposed testicular problems made by a veterinarian, demonstrating a deficiency of medical records in the private veterinary practice in Chile.

The results allow us to conclude that the frequency of hemicastration in elite Chilean rodeo stallions is close to $50 \%$, without a tendency for right or left testicle removal and that the age of hemicastration coincides with the start of competitive sports activity or is slightly later. On the other hand, the main reasons of hemicastration are traumatisms. However, an important percentage is done in a preventive manner or are based on subjective assessments of owners and riders without veterinary diagnosis. Nevertheless, it is unclear that hemicastration affects the athletic performance when it has been carried out preventively or without a veterinary diagnosis. Therefore, hemicastration should only be performed on damaged testicles after veterinary diagnosis. 


\section{REFERENCES}

Apaoblaza SA. 2015. Encuesta sobre ablación testicular unilateral en potros pura raza chilena en las regiones de La Araucanía y Los Ríos. Memoria de título, Universidad Austral de Chile, Facultad de Ciencias Veterinarias. Valdivia, Chile.

Arancio A. 2016. Anuario Federación de Criadores de Caballos Chilenos 2016. $18^{\mathrm{a}}$ ed. Ograma, Santiago, Chile.

Cox JE, Edwards GB, Neal PA. 1979. An analysis of 500 cases of equine cryptorchidism. Equine Vet J 11, 113-116.

de Ban NE. 1970. Castration of horses and complications arising from this procedures. Vet Rec 87, 502-504.

Green P. 2001. Castration techniques in the horse. In Practice 23, 250-261.

Hartman R, Hawkins JF, Adams SB, Moore GE, Fessler JF. 2015. Cryptorchidectomy in equids: 604 cases (1977-2010). J Am Vet Med Assoc 246, 777-784.

Hoagland TA, Ott KM, Dinger JE, Mannen K, Woody CO, et al. 1986. Effects of unilateral castration on morphologic characteristics of the testis in one-, two-, and three-year-old stallions. Theriogenology 26, 397-405.

Huppes T, Stout TAE, Ensink JM. 2017. Decision making for cryptorchid castration: a retrospective analysis of 280 cases. J Equine Vet Sci 48, 73-81.

Lu KG. 2005. Clinical diagnosis of the cryptorchid stallion. Clin Tech Equine Pract 4, 250-256.

Marshall JF, Moorman VJ, Moll HD. 2007. Comparison of the diagnosis and management of unilaterally castrated and cryptorchid horses at referral hospital: 60 cases (2002-2006). J Am Vet Med Assoc 231, 931-934.

Maxwell JAL. 2005. Equine hemi-castration: review of the condition, prevalence, etiology, diagnosis and surgical management. Aust Vet $J$ 83, 203-207.
McCormick JD, Valdez R, Rakestraw PC, Varner DD, Blanchard TL, et al. 2012. Effect of surgical technique for unilateral orchiectomy on subsequent testicular function in miniature horse stallions. Equine Vet J 44 (Suppl 43), 100-104.

Moll HD, Pelzer KD, Pleasant RS, Modransky PD, May KA. 1995. A survey of equine castration complications. J Equine Vet Sci 15, 522-526.

Montory A. 2016. Historia del rodeo chileno. Tomo I. Federación del Rodeo Chileno. Santiago, Chile.

Mora-Carreno M, Briones R, Galecio JS, Parra D, Rosenfeld C, et al. 2014. Main musculoskeletal injuries associated with lameness in Chilean rodeo horses. Arch Med Vet 46, 419-424.

Mueller POE, Parks AH. 1999. Crytorchidism in horses. Equine Vet Educ 11, 77-86.

Muñoz-Alonzo L, Morales F, Ortiz R, Cruces J, Briones M, et al. 2016. Medición testicular en sementales de raza caballo chileno enteros y castrados unilateralmente. Rev Inv Vet Perú 27, 303-308.

Parlevliet JM, Kemp B, Colenbrander B. 1994. Reproductive characteristics and semen quality in maiden Dutch warmblood stallions. J Reprod Fert 100, 183-187.

Searle D, Dart AJ, Dart CM, Hodgson DR. 1999. Equine castration: review of anatomy, approaches, techniques and complications in normal, cryptorchid and monorchid horses. Aust Vet J 77, 428-434.

Stout T, Colenbrander B. 2011. Reproductive parameters of draft horse, friesian and warmblood stallions. In: McKinnon AO, Squires EL, Vaala WE, Varner DD (eds). Equine Reproduction. Vol 1. $2^{\text {nd }}$ ed. Wiley-Blackwell, Chichister, UK, Pp 1362-1366.

Trotter GW. 1993. Unilateral castration. In: McKinnon AO, Voss JL (eds). Equine Reproduction. Lea \& Febiger. Philadelphia, USA, Pp 921-924.

Varner DD, Schumacher J. 1998. Enfermedades del aparato reproductivo: el padrillo. In: Colahan P, Mayhew I, Merritt A, Moore J (eds). Medicina y Cirugía Equina. Vol II. 4ª ed. Inter-Médica, Buenos Aires, Argentina, Pp 773-789. 